\title{
COVID-19. Where did we go wrong?
}

Journal of the Ceylon College of Physicians, 2020, 51, 71

Human beings exploring the entire universe

Exploiting at will, planet's land, trees, rivers

To many warnings of danger, we were averse

Never thought we'll have to pause and reverse

With tsunamis, floods, wildfires, drought

Nature trying its best, to show us its clout

Ignored as trivial, never having any doubt

Not even allowing the dead earth to sprout

How sad we didn't listen to cries of nature

Thought for our use, created every creature

Uncontrolled exploitation, the ugly feature

Mankind is sinking in a suicidal culture

Nations topping the scales of prosperity

Salons, beaches, gun sales given priority

Enjoying themselves with unending variety

Kept us thinking, what a fascinating society!

Then COVID struck, a thundering bang

Everyone is bitten by its poisonous fang

Was a little too late when alarm bells rang

Now locked down, have nowhere to hang
Spending billions of dollars for warfare

Investing little for providing healthcare

In a pandemic contagion caught unaware

Shortages in basic services now laid bare

Even before the epidemic reached its crest

Against the restrictions Americans protest

Encroaching on basic freedoms they detest

With such stupidity, they shall fail the test

Looking for salvation from powers invisible

Hoping the deity found nothing impossible

Could save mankind from disasters horrible

With blind faith, outcome inevitably terrible

With harmless deeds, will reap what we sow

Throughout Sansara the Karma shall follow

As it has been laid down many centuries ago

Observe five precepts, the simplest way to go!

\section{Sarath Gamini De Silva}

30.4.2020 